\title{
The Origins of the "Right and Wrong" Test of Criminal Responsibility and Its Subsequent Development in the United States: An Historical Survey
}

\author{
Anthony Platt* and Bernard L. Diamond**
}

NE OF THE EARLIEST sources of the "right and wrong" test of responsibility, the core of the M'Naghten rules, is Genesis: ${ }^{1}$

And out of the ground the Lord God made to grow every tree that is pleasant to the sight and good for food, the tree of life also in the midst of the garden, and the tree of the knowledge of good and evil. And the Lord God commanded the man, saying, "You may freely eat of every tree of the garden; but of the tree of the knowledge of good and evil you shall not eat, for in the day that you eat of it you shall die."

But the serpent said to the woman, "You will not die. For God knows that when you eat of it your eyes will be opened, and you will be like God, knowing good and evil."

Then the Lord God said, "Behold, the man has become like one of us, knowing good and evil; and now, lest he put forth his hand and take also of the tree of life, and eat, and live for ever"-therefore the Lord God sent him forth from the garden of Eden, to till the ground from which he was taken. ${ }^{2}$

There are, as far as we can ascertain, only six other places in the Old and New Testaments where the phrase, "knowledge of good and evil," or a synonym, can be found. ${ }^{3}$ The meaning of this phrase, as it is used in the Bible and the criminal law, is not at all clear and has traditionally been subjected to ambiguous interpretations. In its original idiomatic

$\dagger$ This research was supported in part by grant number 449 of the Institute of Social Sciences, University of California, Berkeley, from funds derived from the National Science Foundation.

*A.B., 1963, University of Oxford, M. Crim. 1965, University of California, Berkeley. Teaching Ass't, School of Criminology, University of California, Berkeley; Jumior Research Specialist, Center for the Study of Law and Society, University of California, Berkeley.

** A.B., 1935, M.D., 1939, University of California. Professor of Criminology and of Law, University of California, Berkeley.

1 See generally Graves \& Patai, Hebrew Myths: The Book of Genesis 76-81 (1964).

2 Genesis 2:9, 2:16-17, 3:4-5, 3:22-23 (Revised Standard Version). (Emphasis added.)

3 Deuteronomy 1:39; 2 Samuel 14:17; 1 Kings 3:9; Isiah 7:14-16; Jeremiah 4:22; Hebrews 5:14. 
sense it meant the "knowledge of all things, both good and evil," and was not intended to depict man's capacity for moral choice. One Biblical commentator has observed that "the ordinary explanation of the phrase 'good and evil' in the literal sense, assumes that God would for any reason withhold from man the ability to discern between what is morally right and wrong-a view which contradicts the spirit of the scripture." interpretation is supported by the fact that Adam's decision to eat from the tree was in itself a morally significant act.

Although "good and evil"" as originally used, signified perfect wisdom, the phrase as subsequently used does refer more specifically to moral capacity. Thus Solomon asked God to grant him "an understanding mind to govern thy people, that I may discern between good and evil" and in Hebrews, righteousness is said to be found in "those who have their faculties trained by practice to distinguish good from evil." This double meaning of the phrase, one idiomatic and the other literal, is reflected in the modern law of criminal responsibility, which to this day perpetuates the conflict. 5 This article outlines how the "good and evil" test of responsibility found its way imto Anglo-American jurisprudence from Hebrew law, and traces, $\dot{m}$ greater detail, its subsequent development in American criminal law during the early part of the nineteenth century.

I

\section{ANCIENT DOCTRINES OF RESPONSIBILITY}

The earhest legal ideas of responsibility were first generalized in Hebrew law, which distinguished between crimes committed intentionally and umintentionally. The archetypal examples of criminal incapacity were accidental homicide and crimes committed by children or insane persons. With respect to major crimes, ignorance of the law was a good defense, and proof of "forewarning" had to be demonstrated for a successful prosecution. ${ }^{6}$ Whether the wrongful act had been done intentionally or inadvertently was also an important consideration when determining the appropriate punishment. Children and the insane were not legally obligated to compensate the victims of their harmful acts.?

4 The Pentateuch and Haftorahs 10 (Hertz ed. 1956). See also Graves \& Patar, op. cit. supra note 1, at 81, para. 13.

5 See, e.g., People v. Wolff, 61 Cal. 2d 795, 800, 394 P.2d 959, 961-62, 40 Cal. Rptr. 271, 273-74 (1964).

6 Horowitz, The SpIRtr of Jetrish LAw 167-70 (1953).

7 "A deaf-mute, an idiot and a minor are awkward to deal with, as he who injures them is liable (to pay), whereas if they injure others they are exempt." TrE BabyLonian TALMIDd, Baba Kasasa 501-02 (Epstein ed. 1935). "To clash with a deaf-mute, au imbecile, or a minor is bad, seeing that if one wounds one of these, he is hable, whereas if they wound others, they are exempt. Even if a deaf-mute becomes normal, or an imbecile becomes sane, 
The doctrine of criminal responsibility was further elaborated in Greek philosophy and Roman law. Among the Greeks, as elsewhere, the most primitive laws treated intentional homicide more harshly than unintentional homicide. The moral philosophers reflected the assumptions and practices of the courts by recognizing the different kinds of impulses which might motivate harmful acts. ${ }^{8}$ Although Plato argued that the distinction between voluntary and involuntary wrongs was philosophically unsound because unjust acts were always done unwillingly, he nevertheless acknowledged the pragmatic benefits of such a concept and conceded that harms committed with some degree of calculation deserved severer punishments than those committed in the heat of passion. ${ }^{9}$ Plato attributed to human beings "an element of free choice, which makes us, and not Heaven, responsible for the good and evil in our hives."10

For Aristotle, the distinction between voluntary and involuntary acts was more important; he believed moral virtue to be the state of character which allows man to function well in accordance with his nature. Aristotle held that an action is voluntary only if it is not done under compulsion or owing to ignorance; inan, therefore, has the capacity to choose, and this choice is defined as the "deliberate desire of things in our own power."11 To Aristotle, knowledge, rather than forethought, was the real test of responsibihty: A person is morally responsible if, with knowledge of the circumstances and in the absence of external compulsion, he dehberately chooses to commit a specific act. ${ }^{12}$ Children, therefore, can act voluntarily, but because they do not have the capacity to premeditate their acts, they, tike animals and the insane, are not to be considered morally responsible..$^{13}$

Roman law contained only vagne allusions to responsibility for crimes,

or a minor reaches majority, they are not liable for payment inasmuch as they were legally irresponsible when they caused the wound." Code of Mamronides, Book Eleven: The Book OF TORTS 176 (Oberman ed. 1954).

8 "Durmg the fifth century there had clearly been a greater emphasis on fault as the basis of liability, and in the fourth Demosthenes puts the completely different attitude shown to intentional and unintentional injuries among the unwritten laws of nature supported by the universal moral sense of mankind." JONES, THE LAW AND LEGAL THEORY OF TEE Grefrs 264 (1956).

9 PLATO, LAWS, Book IX, 256 (Taylor transl. 1931).

10 Plato, The Repubic 350 (Cornford transl. 1945). See also Agretelis, Mens Rea in Plato and Aristotle, 1 Issues IN CRMmNology 19 (1965).

11 ARtstome, The Nicomachean Etritcs 58 (Ross transl. 1954).

12 "[I]f the acts that are in accordance with the virtues have themselves a certain character it does not follow that they are done justly or temperately. The agent also must be in a certain condition when he does them; in the first place he must have knowledge, secondly he must choose the acts, and choose them for their own sakes, and thirdly his action must proceed from a firm and unchangeable character." Id. at 34 .

13 JoNes, op. cit. supra note 8 , at 273 . 
but the concept of accountability was implicit in analogous areas such as contractual and delictual obligations. The earliest Roman legal sources, such as the Twelve Tables (c. 450 B.C.), referred only briefly to the legal incapacities of children and the insane. ${ }^{14}$ In the third century B.C., however, the Lex Aquilia, which dealt with delictual obligations arising from wrongful damage to property, contained more specific references on accountability: "[A] nan who, without negligence or malice, but by some accident, causes damage, goes unpunished."15

The Lex Cornelia of the time of Sulla provided a criminal or quasicriminal remedy for injuries to person, property, or reputation; the essence of the action was, according to Buckland, "outrage or insult or wanton interference with riglits, any act, in short, wlich showed contempt of the personality of the victim or was of a nature to lower him in the estimation of others, and was so intended."16 Persons lacking the ability to form the intent requisite for willing a harmful act were exempt under the law. Thus, if a child or an insane person committed homicide, he was not to be held accountable because "the one is excused by the innocence of his intentions, the other by the fact of his misfortune."17

Dehctual obligations of children were determined according to age as well as capacity. Infants were children under seven years, and puberty was usually reached at fourteen in males and twelve in females. ${ }^{18}$ Children under seven were considered doli incapax, or incapable of evil intent, whereas those between the ages of seven and fourteen could be held accountable only if proof of intention was clear and certain. Gaius, in his compilation of the second century A.D., noted that at one time there had been a dispute as to the capacity of a young child to incur delictual obligations for theft. "Most lawyers," Gaius noted, "hold that, since theft depends on intention, the child is only liable on such charge if he is approaching puberty and so understands that he is doing wrong (intellegat se delinquere)."19

By the time of Justimian's codification of the law in the sixth century A.D., there was considerable evidence to support the privileged legal status of children and the insane in their delictual and contractual obligations. With regard to the former, Justinian's lawyers observed that "punishunent is to be mitigated of one who committed homicide in a brawl

14 For a general discussion of the Twelve Tables, whose authorship and content are subject to question, see BUCKLAND, A TEXT-BOOK OF RoMaN LaW 1-2 (1963).

151 The Instirutes of GaIUS 223 (Zulueata transl. 1946). For a discussion of the Lex Aquilic, see BuckIAND, op. cit. supre note 14, at 580-82.

16 Id. at 585 .

17 Justintan, Digest 48.8.12.

18 MoyLe, IMPERATORIS IUSTINTANI INSTITUTIONUAI 416-17 (1955).

191 INsTITUTEs, op. cit. supra note 15, at 223. 
by accident rather than of his own free will." ${ }^{20}$ As for contractual liability, children and the insane enjoyed similar protection, for they were generally regarded as deficient in discretion and intellectual capacities. A child, reported Justinian, was "not very different from a madman,"21 though he was allowed to make contracts which were to his advantage; in other cases, a child could not make a contract without his tutor's authority. An insane person, however, was completely incapable of contracting, because "he does not know what he is doing." was not responsible for his harmful acts and was "excused by his madness."

\section{II}

\section{MEDIEVAL CONCEPTS OF RESPONSIBILITY}

The doctrine of mens rea in modern criminal law presupposes a dualism of mind and body and the existence of "mental states" whicl cause external acts. In law this concept is usually expressed in terms of freedom of the will. The definition and boundaries of "free will" were expounded in the Middle Ages, and many writers argue that the genesis of the doctrine of mens rea "is to be found in the mutual influences and reactions of Christian theology and Anglo-Saxon law."24 On the other hand, it is probably more accurate to say that the idea of mens rea has its intellectual roots in Hebrew or Talmudic law and in the moral philosophy of Plato and Aristotle, but that it remaimed for Christian ethics to extend and elaborate upon its metaphysical and pragmatic ramifications.

The social control of criminals and deviates during the medieval period was guided by the moral dogmata reflected in theological literature. Early English law reports very few cases of criminal incapacity but those who promulgated principles of law had no difficulty in finding religious concepts to justify and validate a umique role for children and the insane. Children, especially, were the subject of great interest and concern; medieval theology contains descriptive and doctrinal accounts of baptisn, the moral development of the child, parental responsibility, and the socialization of young persons by way of rehgious institutions. This concern for the child's "innate ignorance" was a function of the Church's political interest in recruiting and controlling new members rather than of benign paternalism. As an indirect result of this emphasis on induction ceremonies, however, the Church estabhished different standards of

\footnotetext{
20 JUSTINian, Digest 48.8.3.

21 JUSTINIAN, INSTITUTES 3.19.9.

22 Ibid.

23 Justnutan, Digest 48.8.12. In English law this maxim was commonly written as furiosus solo furore punitur.

24 Lévitt, The Origin of the Doctrine of Mens Rea, 17 Ir工. L. REv. 117, 136 (1922).
} 
treatment for the child, which ultimately affected socio-ethical concepts of responsibility. ${ }^{25}$

It is in this period's theological speculation concerning the nature of childhood that one again finds reference to the concept and phrase, "knowledge of good and evil." Children, according to medieval moral theology, are incapable of personal sin, although tainted by original sim. According to Augustine, all men are born with the guilt of original sin and are therefore incapable of acting without sin; they can, however, choose to do good through divine grace, and God does not require man to do that which is impossible for human volition. Man is expected to overcome evil by overtly consenting to do good; "it is one thing to be ignorant, and another thing to be unwilling to know."2B

Augustime held that children, although capable of sin, are incapable of voluntarily acknowledging and freely pursuing sin. They are protected and excused by their "profound ignorance, their great weakness of mind and body, their perfect ignorance of things, their utter inability to obey a precept, the absence in them of all perception and impression of either natural or written law, the complete want of reason to impel them in the direction of either riglit or wrong." They are immune to sanctions or rewards until "they are of age to know their father and mother"; they are "incapable of inoral government" and "completely involved and overwhelmed in a cloud of darkness and ignorance."27

Bede and other contemporary writers of the Church emphasized the mental elements of crime, with special reference to the nature of conscience and the benefits of confession. Children, Bede wrote, are not capable of "inner depravity" in their early years because they can "will nothing of good or ill."28 This concept was uniformly accepted by the Patristic Fathers, the writers of moral treatises, the followers of Abailard and Aquinas, and eventually the judges and jurists of England in the fourteenth century. By the twelfth century, there was growing support for the view that inan is a free individual, morally and rationally autonomous, and unaffected by an inherent attachment to general humanity. Abailard and Aquinas, for example, stressed man's subjective capacity

${ }^{25}$ For a general view of how Christian ethics permeated the whole human fabric, see de Wulf, Pancosophy and Cinizization in the Miodle Ages (1922).

${ }^{26}$ Augustine, The Antr-Pelagian Works, On Grace and Free Will, ch. 5. "We sin either because we do not know what we ought to do, or because we do what we already know we should not do. The first, that of sinning without knowing the wrongness of a thing, is the sin of ignorance. The second, that of sinning while knowing a thing to be wrong, is the sin of weakness." AUGUSTINE, ENCEIRmion ch. 81. (The works of Augustine cited in notes 26 and 27 were translated by Jerry R. Craddock, Dep't of Romance Philology, University of California, Berkeley, in June 1965.)

27 Augustine, ON THE Forgiveness of Sins and Baptisas Book I, ch. 66-67.

28 The Venterabie Bede, in Cantica Canticorum atregorica Expositio, hib. I, 1070. 
to make moral distinctions and further argued that children are incapable of personal sin until they reach the age of intellectual and moral discernment. One influential moral treatise of the fourteenth century included the observation that both children and the insane are unable to understand the nature and effects of their harmful acts:.

The first [kind of freedom] is a free-will whereby he [man] can choose and freely do either good or evil. This freedom he has freely [gratuitously] from God so that no one can [make him] do wrong nor can all the devils of hell strengthen man's will to do one sin against his will. For if man did that sin against his will, it would not be a sin. For one does not sin because he cannot escape; as St. Augustine says: All men have freedom but it is restrained in children, in fools, and in the witless who do not have reason whereby they can choose the good from the evil. ${ }^{29}$

\section{III \\ THE "GOOD AND EVII" TEST IN ENGLISH LAW"}

The first known use of the "good and evil" test of responsibility in English criminal law came in the early fourteenth century; since the phrase appears without explanation or justification, one inust assume that it was commonly used by judges of that period and that its meaning was commonly understood. The source of the phrase must have been either the Bible, particularly Genesis, or any of the numerous secondary theological sources which were familiar to the Enghish judges of the fourteenth century. The case is reported in the Eyre of Kent for the year 1313: "An infant under the age of 7 years, though he be convicted of felony, shall go free of judgement, because he knoweth not of good or evil (comsaunt de bien ne de mal) ...."31

In early English law, children over twelve years were held to be as responsible as any adult for their crimes; children under seven years, however, were considered legally incapable of committing a crime. The child under twelve but over seven years could be found guilty if malice and discretion were proved. ${ }^{32}$ Thus in 1338, Judge Spigurnel "found that an infant of 10 years of age killed his companion and concealed him; and he caused him to be hung, because by the concealment he showed that he

29 MrChet, Ayendit of INWTt, or REMorse of Conscience 86 (Morris ed. 1866). This treatise was written in 1340 .

${ }^{30}$ The development of the "good and evil" test in English criminal law is traced more systematically in Platt, The Criminal Responsibility of the Mentally IIl in England, 11001843 (unpublished thesis at University of California, Berkeley, School of Criminology 1965).

31 Y.B., 6 \& 7 Edw. 2, in 24 SELDEN SocteTy 109 (1909).

32 See generally Kean, The History of the Criminal Liability of Children, 53 L.Q. REv. 364 (1937). 
knew how to distinguish between evil and good. And so malice makes up for age (malitia supplet aetatem)."

During the fourteenth, fifteenth, and sixteenth centuries, the rules of infant capacity remained constant in English law; the "good and evil" test was regularly cited by judges and legal commentators. ${ }^{34}$ By the time of Elizabeth I (c. 1581), there existed a legal rationale for the exclusion of special groups from criminal responsibility. Infants and the insane both generally failed to possess the necessary mental capacity to commit a crime; they were treated as "non-persons" because of their supposed lack of understanding, intelligence, and moral discretion. Moreover, they were not considered fit subjects for punishment since they did not comprehend the moral implications of their harmful acts. Children, the insane, and idiots enjoyed a privileged position in English civil law as well, especially in regard to the laws of guardianship and contractual liability.

Very few cases of insanity were reported in English criminal law before the seventeenth century, and it is reasonable to infer that only the most gross and dramatic kinds of mental illness were acknowledged in mitigation of responsibility. ${ }^{35}$ The criminal law generally perceived the insane person as resembling a young child in terms of his moral development and cognitive abilities. According to the Elizabethan writer, Lambard:

If a mad man or a naturall foole, or a lunatike in the time of his lunacie, or a childe $y$ apparantly hath no knowledge of good nor evil, do kil a ma, this is no felonious acte, nor any thing forfeited by it ... for they cannot be said to have any understanding wil. ${ }^{\mathbf{8 6}}$

Edward Coke, writing in the latter part of the sixteenth century, did not mention the "good and evil" test but did compare the mental deficiencies of madmen with the mental capacity of children; he also noted the age of responsibility was fourteen years. ${ }^{37}$ Coke was the first English jurist to attempt anything like a scientific treatment of the criminal law, and his partial codification of the common law encouraged other commentators to remedy existing conceptual gaps. The rules of responsibility for the insane were extremely inadequate compared with those for children. It was not difficult, however, for judges to rectify this deficiency by analogy

33 Y.B., 11 \& 12 Edw. 3, 626 (Horwood ed. 1883).

84 See Platr, op. cit. supra note 30, at 53-78.

35 Platt \& Diamond, The Origins and Development of the "Wild Beast" Concept of Mental Illness and Its Relation to Theories of Criminal Responsibility, $1 \mathrm{~J}$. OF THE HrsTORX OF THE BEHAVIORAI SCIENCES 355 (1965).

36 Lambard, Eirenarcha, Or of The Office of Itustices of Peace 218 (1581).

372 Coke, Institutes of the Laws of England, oR A Commentary Uron Litrleton 247 (11th ed. 1719). See also Kean, supra note 32 , at 370. 
to the "good and evil" test which had long been used to distinguish between the infant who was innocent of moral guilt and the older child who was doli capax.

By the end of the sixteenth century, the courts had begun to apply the test of "knowledge of good and evil" to the insane. Michael Dalton's legal manual, The Countrey Justice, first published in 1618, contains the first known written acknowledgment of the "new" test for the insane. Dalton was not an important judge, and his treatise is not a recognized judicial authority; ${ }^{38}$ either he made a mistake in copying the precedents or he was just reporting accepted practice. In view of the steady legal development of the "good and evil" test and the close jurisprudential relationship between the concepts of infancy and insanity, the latter view is unore likely correct. Dalton reported that:

If one that is "non compos mentis" [mad], or an ideot, kill a man, this is no felony; for they have not knowledge of good and evill, nor can have a felonius intent, nor a will or minde to doe harm. ... An Infant ... may commit Homicide, and shall bee hanged for it, viz. if it may appeare ... that he had knowledge of good and evill, and of the perill and danger of that offence. ${ }^{39}$

After Coke, Matthew Hale is perhaps the most siguificant figure in English legal history. In a lengthy discussion of infant capacity, he approved the earher decisions and mentioned the "good and evil" test five times; for example, he noted that "it is clear that an infant above fourteen and under twenty-one is equally subject to capital punishments, as well as others of full age; for it is 'praesumptio juris', that after fourteen years they are 'doli capaces', and can discern between good and evil."'0 As for insanity, Hale improved upon earlier definitions, stating that "such a person as labouring under melancholy distempers hath yet ordinarily as great understanding, as ordinarily a child of fourteen hath, is such a person as may be guilty of treason or felony." 41 This definition of insanity relied on analogy to the "good and evil" test, a fact which critics

38 Dalton does not cite Lambard, but it seems likely that he was familiar with Lambard or at least with some other (now unknown) Elizabethan legal source. It is hardly possible that he would have presumed to have initiated his own formulation without reference to previous authoritative sources. Assuming that he knew Lambard's writing, it is conceivable that he failed to note that Lambard's qualifying phrase, "y apparently hath no knowledge of good nor evil," could be interpreted as applying only to the child and not to "mad man, or a naturall foole, or a lunatike in the time of his lunacie." He (or some other legal writer or judge) may have assumed that the good and evil phrase applied equally to all, as does Biggs in The Guilty Mind (published in 1955).

39 Dalton, The Countrey Justice 244 (1630).

401 HaLe, The History of the Pleas of The Crown 25 (1736).

41 Id. at 30 . 
have failed to observe. Hale's test was neither revolutionary, nor unsupported by any authority, ${ }^{42}$ nor based on personal ignorance. ${ }^{48}$ On the contrary, it was sonrething of an improvement on earlier definitions, and it was certaimly an appropriate interpretation in the light of contemporary legal knowledge. The Englisl legal scholar, William Blackstone, whose contributions are discussed in the section on American criminal law, approved Hale's test of responsibility.

In the eiglteenth century, the "good and evil" test was regnlarly used in both insanity and infancy cases." In Rex v. Arnold (1724), the jury was instructed that the defendant was not to be held insane if he "was able to distinguish whether lie was doing good or evil ...."45 The same test was used in Rex v. Ferrer ${ }^{46}$ (1760), Parker's Case ${ }^{47}$ (1812), Bellingham's Case ${ }^{48}$ (1812), Rex v. Bowler ${ }^{49}$ (1812), Martin's Case ${ }^{50}$ (1829), Offord's Case" (1831), and Oxford's Case ${ }^{62}$ (1840). The "good and evil" test was momentarily abandoned in Hadfield's Case (1800) as a result of the brilliance and oratory of the defense counsel, Thomas Erskine, ${ }^{63}$ but this decision lad no lasting effect on the rules of criminal responsibility for the insane. By the time M.'Nagliten was tried for the murder of Edward Drummond in 1843, the earlier test of responsibility liad been re-established.

Although M.'Naghten was acquitted and committed to a nrental hospital, the case provoked public anger and political repercussions. Governmental pressure, aggrandized by the rigliteous indignation of Queen Victoria who feared that the acquittal might encourage cranks and radicals to nrake attempts on ler life, was brought to bear upon the judges in

42 Perkins, Crtamtar Law 740 (1957).

482 Stephen, A History of the Crmimal Law of Engiand 150 (1883).

44 "But those that are to be esteemed guilty of any offences must have the use of their reason, and be at their own disposal or liberty. For those that want reason to distinguish betwixt good and evil (as infants under the age of discretion (viz.), under the age of fourteen years, ideots, lunaticks etc.) ought not to be prosecuted for any crime." WoOD, AN INSTITUTE OF THE LAWS OF ENGLAND 339 (1728).

4516 Howert, A Comptete Colfiction of Státe Triats [bereinafter cited as Howerc] 695,765 (1724).

4619 HOWELI 885, 959 (1760).

47 Collinson, Itiots, Lonatics, and Other Persons Non Concrotes Mentis 477 (1812).

$48 \mathrm{Id}$. at 636,657 .

49 Id. at 673 .

60 Saglford, Lunatics, Idiots, and Persons of Unsound Mind 465 (1833).

615 Car. \& P. 168 (1831); Lloyd, Insanity: Forms and Medico-Legal Relations, in Wirarton \& StIEIE, Medicax JURISPRUdence $\$ 498$ (5th ed. 1905).

529 Car. \& P. 525 (1840); Wearton \& STIIIE, op. cit. supra note 51, at $\$ 500$.

5327 Howell 1281 (1800); see 1 The SpeEches of THE Hon. Thouras ErsknNe 495 (Ridgway ed. 1813). 
the House of Lords. ${ }^{54}$ Consequently, the "Law Lords" re-examined the rules of responsibility and the "anti-M'Naghten Rules," as Koestler called them, ${ }^{50}$ resulted. In essence, the judges held that:

[T] o establish a defence on the ground of insanity, it must be clearly proved that, at the time of committing of the act, the party accused was labouring under such a defect of reason, from disease of the mind, as not to know the nature and quality of the act he was doing: or, if he did know it, that he did not know he was doing what was wrong. The mode of putting the latter part of the question to the jury on these occasious has generally been, whether the accused at the time of doing the act knew the difference between right and wrong. ${ }^{56}$

During the early nineteenth century, the phrases "good and evil" and "riglt and wrong" were used interchangeably and synonomously. The first known substitution of "right and wrong" for "good and evil" was in Parker's Case $^{57}$ (1812), in which the Attorney-General argued that "before it could have any weight in rebutting a charge [treason] so clearly made out, the jury must be perfectly satisfied, that at the time when the crime was committed, the person did not really know right from wrong." In Bellingham's Case ${ }^{58}$ (1812), both phrases were used, and Lord Chief Justice Mansfield instructed the jury that "the single question was, whether, at the time this fact [murder] was committed, [the defendant] ... possessed a sufficient degree of understanding to distinguish good from evil, riglit from wrong." In the United States, these two phrases were also used synonomously in both infancy and insanity cases. ${ }^{59}$

IV

CONCEPTS OF RESPONSIBILITY IN THE UNITED STATES

A. Criminal Responsibility of Children, 1800-1900

The responsibility of children in the United States during the nineteenth century was formulated according to traditional common law prin-

54 Diamond, Isaac Ray and the Trial of Daniel M'Naghten, 112 ANERTCAN J. OF PsXCruatrX 651, 655 (1956).

55 KoestreR, REFLECTIONS ON HANGENG 75 (1955).

60 Regina v. M'Naghten, 10 Clark and F. 200, 8 Eng. Rep. 718 (1843). (Emphasis added.)

57 Colmnson, op. cit. supra note 47 , at 477 .

$58 \mathrm{Id}$. at $65 \%$.

59 In an important California murder case, Judge Dwinelle instructed the jury that: "A person sometimes insane, who has lucid intervals, or is so far sane as to distinguish good from evil, right from wrong, may commit a crime and be legally held responsible." Marse \&

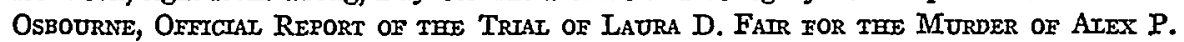
CRITTENDEN 323 (1871). Both of the phrases, "good and evil" and "right and wrong," were also used in cases of infant incapacity. See, e.g., State v. Gom, 9 Humph. 118 (Tenn. 1848). 
ciples and especially to the works of William Blackstone. His Commentaries contain a systematic treatment of the criminal law, and his summary of the criminal incapacity of children was, in effect, incorporated into American law. The Commentaries served as a model for contemporary jurists; judges also cited his theoretical statements to justify specific decisions:

By the law, as it now stands, and has stood at least ever since the time of Edward the Third, the capacity of doing ill, or contracting guilt, is not so much measured by years and days, as by the strength of the delinquent's understanding and judgment. For one lad of eleven years old may lave as much cunning as another of fourteen; and in these cases our maxim is, that "malitia supplet aetatem." Under seven years of age indeed an infant cannot be guilty of felony; for then a felonious discretion is almost an impossibihity in nature: but at eight years old he may be guilty of felony. Also, under fourteen, though an infant shall be prima facie adjudged to be doli capax; yet if it appear to the court and jury that he was doli capax, and could discern between good and evil, he may be convicted and suffer death. Thus a girl of 13 has been burnt for killing her mistress; and one boy of 10 , and another of 9 years old, who had killed their companions, have been sentenced to death, and he of 10 years actually hanged; because it appeared upon their trials, that the one hid himself, and the other hid the body he had killed; which hiding manifested a consciousness of guilt, and a discretion to discern between good and evil. And there was an instance in the last century, where a boy of 8 years old was tried at Abingdon for firing two barns; and, it appearing that he had malice, revenge, ancl cunning, he was found guilty, condemned and hanged accordingly. Thus also, im very modern times, a boy of ten years old was convicted on his own confession of murdering his bedfellow; there appearing in his whole behavior plain tokens of nischievous discretion; and as the sparing this boy merely on account of his tender years might be of dangerous consequence to the public, by propagating a notion that children might commit such atrocious crimes with impunity, it was unanimously agreed by all the judges that he was a proper subject of capital punishment. ${ }^{\text {o }}$

American case law on the criminal responsibility of children was more elaborate and sophisticated than its English counterpart. Additionally, some of the same cases developed rules of evidence for the protection of young offenders.

In State v. Doherty ${ }^{61}$ (1806), a young girl between 12 and 13 was indicted for the murder of her father. When challenged by the court she remained mute, and a plea of "not guilty" was entered on her behalf. During the trial, "the defendant stood up erect in the bar several hours,

604 Blackstone, Comomentaries *23-24.

612 Tenn. 79 (1806). 
her countenance was ghastly pale, without the least expression, or indication of understanding." ${ }^{\prime 62}$ On the question of responsibility, Judge White instructed the jury that:

Their inquiry was, whether the prisoner was the person who took the life of the deceased, and, if they were of that opinion to inquire whether it were done with malice aforethought. If a person of fourteen years of age does an act, such as stated in this indictment, the presumption of law is that the person is "doli capax." If under fourteen and not less than seven, the presumption of law is that the person cannot discern between right and wrong. But this presumption is removed, if from the circumstances it appears that the person discovered a consciousness of wrong. ${ }^{63}$

The jury returned a verdict of not guilty.

In State v. Aaron ${ }^{64}$ (1818), a young Negro slave of 11 years was accused of murdering another young child. Although there was circumstantial evidence that the defendant had known the victim as a playmate and had been working in the field where the murder took place, he at first denied the crime. Following the inquest, "he was taken apart by one or more of the jurors and told that he had better confess the whole truth, and he did then confess that he had thrown the child into the well, in which the body had been found, and from which he had seen it taken ...." ${ }^{165}$ At the trial he again denied the crime but was convicted and sentenced to death. On appeal to the Supreme Court of New Jersey, counsel for the defendant claimed that the prosecution had failed to rebut the presumption that a child of 11 years is incapable of coinmitting a crime. Chief Justice Kirpatrick ordered a new trial on the grounds that the defendant had been convicted by a mere naked confession, uncorroborated, and obtained by pressure, which should not have been admitted as evidence. (The trial judge had justified the extortion of the confession on the grounds that "it was the anxiety only of a moral and religious community, seeking to discover the perpetrator, that it might be purged from the guilt of shedding blood." ${ }^{\text {"60 }}$ ) The Chief Justice held

62 Id. at 82 .

63 Id. at $8 \%$.

644 N.J.L. 263 (1818).

$65 I d$. at $272-73$.

${ }^{66} I d$. at 278 . The trial judge subsequently restated the rules of responsibility for children: "The great subject of inquiry in all cases, ought to be, the legal capacity of the prisoner; and this is found in some, much earlier than others. The real value of the distinctions is to fix the party upon whom the proof of this capacity lies. There is indeed an age so tender that the nature and consequences of acts cannot be compreliended, and every uncorrupted feeling of the heart, as well as every moral and legal principle, forbids punishment. But after we pass this age and progress towards maturity, there have been periods settled, which ascertain the presumption of law, as to the existence of this capacity. If under fourteen, especially under twelve years, the law presumes that it does not exist and 
that the presumption of innocence on the part of the defendant could only be rebutted "by strong and irresistible evidence that he had sufficient discernment to distinguish good from evil." Were it demonstrated that the defendant could "comprehend the nature and consequences of his act, he may be convicted and have judgment of death. . . . With respect to confessions im general," the judge continued, "and especially with respect to the confessions of infants, it is necessary to be exceedingly guarded." Confessions obtained "by the flattery of hope or by the impression of fear, however slightly the emotion may be implanted, [are] not admissible evidence." $" 18$

In State v. Bostick ${ }^{69}$ (1845), the defendant, a white girl of twelve years, was indicted for arson. Mary Bostick had been a servant of Mrs. Ann Fisher who described her: as a "very shrewd, artful girl; not intelligent, or very capable of learning; but smart to work, and shrewd in mischief." The defendant had confessed to her mistress that sle had set fire to the house on purpose. Two young children who had been in the charge of the defendant had been burnt to death, and the prosecution sought to establish the malicious motivation of Mary Bostick. The defendant appealed on the ground that the confession had been improperly obtained, "as being brought about by promises, or inducements of favor." A majority of the court agreed and ruled out the confession and acquitted the defendant.

One or two unavailing attempts had been made, to induce her to confess. Afterwards her mistress took her into another room, and questioned her whether she did the act. The child at first denied it. Her mistress then told her, "that she was suspected of the offence, and if she confessed it, the suspicion would not be stronger; that she (the mistress) did not expect to do anything with her, but was going to send her home." The prisoner then confessed, that when she went upstairs in the evening, she placed the candle under the clothes which hung from the bed. Here then is an inducement to confess; a promise of favor held out by a person in authority, and a hope raised in the mind of the child, that she would be sent to her home. Hence, a doubt and uncer-

if the state seek to punish, it must conclusivcly establish it. If above the age of fourteen, the law presumes its existence, and if the accused would seek to avoid punishment, he must overcome that presumption by sufficient evidence. But wherever the capacity is established, either by this presumption of law or the testimony of vitnesses, punishment always follows the infraction of the law. If the intelligence to apprehend the consequences of acts; to reason upon duty; to distinguish between right and wrong; if the consciousness of guilt and innocence be clearly manifested, then this capacity is shown: in the language of the books, the accused is 'capax dob', and as a rational and moral agent, must abide the results of his own conduct." Id. at 279. (Emphasis added.)

67 Id. at 271.

68 Id. at 272 . (Emphasis in the original.)

694 Dcl. (4 Harr.) 563 (1845). 
tainty arise, whether the confession was not made, more under the influence of hope, than from a consciousness of guilt. ${ }^{70}$

In Walker's Case $^{71}$ (1820), a young boy just over seven years was indicted for petit larceny. The boy's mother said that "his senses were impaired," and the prosecutor offered no evidence to demonstrate his mental capacity to commit a criminal act. The defense submitted that:

[A]s a child of seven was held incapable of crime, and between that age and fourteen it was necessary to show his capacity; and that, in proportion as he approached to seven, the inference in his favour was the greater, and as he approached to fourteen the less, that there was not sufficient evidence in this case to support the prosecution, especially as strong evidence of incapacity had been produced on his part. ${ }^{\mathbf{7 2}}$

Upon this principle, the Mayor charged the jury, who immediately acquitted the defendant.

Stage's Case $^{73}$ (1820) involved a group of children, between the ages of seven and fourteen, who were indicted for grand larceny. George Stage, who was eight years old, was arrested while trying to escape from a private house with a stolen bear skin. In convicting and sentencing the defendant to three years in the state prison, the court held:

[W]ith regard to an infant, between the age of seven and fourteen, the Jury should be satisfied that he had a capacity of knowing good from evil. And proof of this may be given either by extrinsic testimony, or it may arise from the circumstances of the case. In this case, the fact of concealment, and of an attempt to escape, appear; and it will rest with the Jury to determine, whether this boy did not know, at the time he stole this property, that he was doing wrong. ${ }^{74}$

In People v. Davis ${ }^{75}$ (1823), William Davis, fifteen, and James McBride, thirteen, were indicted and pleaded "not guilty" to a charge of grand larceny. The recorder instructed the jury that:

[T] he presumption of law was in favor of an infant under fourteen years of age, that under seven the law supposed the infant incapable to commit a crime. He is supposed to want discretion to judge between right and wrong; but from that age to fourteen, the law still supposed him innocent, and in order to show his liability for crimes, it was necessary to prove his capacity, that it was the province of the jury to say, from all the evidence before them, whether James McBride was guilty or not guilty; that he was present, and assisted in felony, was satisfactorily proved, but whether liable on account of his tender

\footnotetext{
70 Id. at 565 .

715 City-Hall Recorder (New York City) 137 (1820).

$72 I d$. at 138 .

73 Id. at 177 .

$74 I d$. at 178 .

761 Wheerer, Crominal Law Cases 230 (1823).
} 
years, was the point for them to decide, no proof of his capacity or incapacity had yet been given; the presumption was therefore in his favor up to the period the law supposed he has attained his capacity. ${ }^{76}$

The jury rendered a verdict of guilty against Davis, and not guilty for McBride.

In People v. Teller ${ }^{77}$ (1823), Jason Teller, thirteen, and William Teller, who was over fourteen, were indicted for petit larceny after the stolen property had been found in their possession and both had confessed to the crime. The evidence of Jason's capacity was unsatisfactory; some of the police officers, who knew the boy, thought him active, shrewd, and intelligent, while others had a different opinion of his capacity. The jury returned a verdict of guilty against William Teller and of not guilty for Jason Teller. In a note to this case, the reporter reviewed English and American law on the subject of the criminal responsibility of children. He quoted Hale, Hawkins, and Blackstone, noting that their "principles have long been established in Great Britain and have been adopted in this country. Their decisions, therefore, upon this subject are good authority here." The reporter then summarized the principles of capacity:

Infancy is a satisfactory excuse for the commission of any crime up to the period of seven years, and may or may not extend to fourteen. But upon the attainment of that age, the person of an infant is placed precisely upon the same footing as the rest of mankind, as it respects their accountability for crimes; for at and after this period, the law supposes the party has attained a judgment capable, and a conscience willing to decide between right and wrong.78

If the circumstances under which a felony is committed by an infant between 7 and 14 years of age, indicate that he was doing wrong while stealing, this is tantamount to evidence of his capacity. ${ }^{79}$

In State v. Guild ${ }^{80}$ (1828), a Negro slave, aged twelve, was accused of beating to death an old woman. The defendant confessed to the crime but the question of his capacity to form intent was disputed. The prosecution sought to establish that the defendant was "a cunning smart boy," "full of mischief," "smarter than common black boys of his age," and "ingenious," and "acute in many things." 81 A witness for the defense

76 Id, at $230-31$.

77 Id. at 231.

$78 I d$, at 231-32.

79 Id. at 233-34. In Commonwealth v. Elliot, 4 Law Rep. 329 (1842), a boy of twelve years was acquitted of a charge of murder: "The defense ... rested mainly on the entire want of any adequate motive for so malignant an act; on the youth and inexperience of the prisoner...."

8010 N.J.L. 163 (1828).

81 Id. at 170 . 
admitted that "he knows the difference between good and evil" and had "intelligence enough to know when he did wrong [and] capacity enough to distinguish between right and wrong." 82

In the trial court, Judge Drake instructed the jury as to the presumption in favor of persons between seven and fourteen, and told thein that, to find the defendant guilty, they must realize that

at the age of this defendant, sufficient capacity is generally possessed in our state of society, by children of ordinary understanding, and having the usual advantages of moral and religious instruction. You will call to mind the evidence on this subject; and if you are satisfied that he was able, in a good degree, to distinguish between right and wrong; to know the nature of the crime with which he is charged ... his infancy will furnish no obstacle, on the sense of incapacity, to his conviction. $^{83}$

On appeal, the Supreme Court of New Jersey upheld the verdict of the lower court and, apparently, ignored the principles relating to confessions established in State v. Aaron ${ }^{84}$ The court approved Blackstone's opinion that "mischievous discretion" was sufficient proof of criminal capacity and held that the defendant was a rational and moral agent who should be judged by his act and motives. ${ }^{85}$ The defendant was subsequently sentenced to death and executed.

In Godfrey v. State ${ }^{86}$ (1858), a young Negro slave, about eleven, was indicted for the murder of a four-year-old child, who liad been in his charge. The defendant claimed that "an Indian had done it; that they hunted for Indians, but could not find any." Several witnesses for the prosecution testified that "the [dead] child was on the floor, all bloody; that he was cut on the face and head, three cuts, and a bruise as if with the liead of a hatchet; ... his brain was projecting from his skull." There was further evidence agamst the defendant that he liad been covered by blood and had been wet; the hatchet liad been found in a bucket of

82 Ibid.

83 Id. at 174.

84 See note 64 supra. The court, in Guild, said that "although an original confession may have been obtained by improper means, subsequent confessions of the same or of like facts may be admitted, if the court believes from the length of time intervening, from proper warning of the consequences of confession, or from other circumstances, that the delusive hopes or fears under the influence of which the original confession was obtained, were entirely dispelled." 10 N.J.L. at 180-81.

85 The Chief Justice approved the following statement from Leach's edition of Hawkins: "[F]rom this supposed imbecility of mind, the protective humanity of the law will not, without anxious circumspection, permit an infant to be convicted on his own confession. Yet if it appear, by strong and pregnant evidence and circumstances; that be was perfectly conscious of the nature and maligirity of the crime, the verdict of a jury may find him guilty and judgment of death be given against him." Id. at 189.

8031 Ala. 323 (1858). 
water. One witness testified that Godfrey had said on the evening of the killing that he had killed Lawrence because he had broken his kite, and he would do it again if they did not hang him. There was conflicting evidence as to the character and intelligence of the defendant: One neighbor observed that he is "a smart, intelligent boy, heap smarter than boys of twelve years generally are," another described him as "kind and gentle" and probably not yet eleven years old.

The jury was informed of the presumption in favor of the defendant because of his age and further instructed that:

[T] hey must take into consideration his condition as a negro and a slave, with all the evidence in the case; and that unless [they were satisfied from the evidence] ... that he was fully aware of the nature and consequences of the act which he had committed, and had plainly shown intelligent malice in the manner of executing the act, they should render a verdict of not guilty $\ldots . .87$

The jury returned a verdict of guilty but the presiding judge, doubting the propriety of passing sentence under the circumstances of the case, reserved the question for the decision of the appellate court. On appeal, the Supreme Court of Alabama affirmed the judgment, citing State v. Guild $d^{88}$ in which "a negro slave, of less than twelve years was convicted of murder and executed," and approving the good and evil test, as stated in State v. Aaron. ${ }^{89}$

In State v. Learnard ${ }^{30}$ (1869), the defendant, a male adult, was charged with a burglary and larceny which had been effected by his two children, a boy of about sixteen and a girl of about thirteen. The boy had been prosecuted in a prior term and, on his plea of guilty, was sentenced to the reform school. The defendant pleaded that he was not a principal to the offense because "a girl thirteen or fourteen years old, of good size, and ordinarily intelligent, who was capable of working away from home for wages, and who had done so, is of sufficient discretion to be responsible for what crimes she commits." ${ }^{\prime 1}$ For the defendant, one witness testified concerning the girl's capacity to commit a crime: "She worked for me; I think she earned one dollar per week; she appeared to have intelligence; think she could distinguish between right and wrong. Don't think she ever attended sabbath school; don't think her morals very good." 192 The jury returned a verdict of guilty, stating that the daughter "was under the

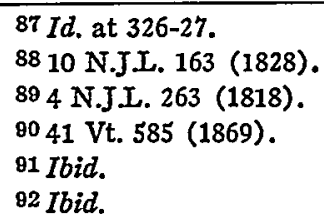


age of discretion and had not sufficient discretion to be responsible for this act, that she entered the store, and took the goods, by direction of the respondent, that the respondent by said threats compelled his daughter to enter the store and take the goods, and that she committed the act through fear of loss of her life .... ."93

On appeal, the defendant claimed there was sufficient evidence to demonstrate that the girl "could distinguisl right froin wrong" and therefore had "sufficient degree of discretion" to render her guilty of a crime. In dismissing the appeal, it was held that any doubt should operate in favor of a young child in "the dubious stage of discretion"; the law "has never undertaken to say that any defined physical dimensions or strength, and being 'ordinarily intelligent, and working away from home for wages,' constitute the capacity for crime, or the criterion of such capacity."94

In Angelo v. People ${ }^{95}$ (1880), Theodore Angelo, eleven, was charged with lomicide. He was convicted of manslaughter and the jury sentenced him to the pententiary for six years. A motion for a new trial was overruled by the court, and lie was re-sentenced to the reform school for four years. On appeal to the Supreme Court of Mlinois, the defendant said that his capacity and malice had not been proved "beyond a reasonable doubt." In Illinois, a child under ten years was legally incapable of coinmitting a crime, and between the ages of ten and fourteen lie was prima facie incapable and deemed doli incapax.

In a highly sophisticated and compassionate opinion by Justice Walker, ${ }^{96}$ the court reversed the decision of the trial court on the grounds that there was no evidence as to the defendant's capacity.

[T]he rule required evidence strong and clear beyond all doubt and contradiction, that he was capable of discerning between good and evil; and the legal presumption being that he was incapable of committing the crime, for want of such knowledge, it devolved on the People to make the strong and clear proof of capacity, before they could be entitled to a conviction. This record may be searched in vain to find any such proof. There was no witness examined on that question, nor did any one refer to it. There is simply evidence as to his age. For aught that appears, he inay have been dull, weak, and wholly inca-

93 Id. at 587.

94 Id. at 589 . (Emphasis added.)

9596 IIl. 209 (1880).

90 Justice Walker criticized the prosecution counsel for proposing to the jury that the defendant's refusal to take the witness stand should be taken as evidence of his guilt. "We can not conceive that any member of the bar could deliberately seek by such means to wrongfully procure a conviction and the execution of a fellow being, when his highest professional duty to his client only requires him to see that there is a fair trial according to the law and evidence." Id. at 213. 
pable of knowing good from evil. It does not appear, from even the circumstances in evidence, that he may not have been mentally weak for his age, or that he may not have even approached idiocy..$^{97}$

In State v. Toney ${ }^{98}$ (1881), Lawrence Toney, about twelve, and others were charged with malicious trespass. The jury determined that the defendant, "a well-grown boy, apparently at least over twelve years," was guilty because "he was conscious that his act was wrongful" and "he could discern between right and wrong." On appeal, the Supreme Court of South Carolina affirmed: The "evidence of malice was strong and clear, beyond all doubt and contradiction."

In State v. Adams ${ }^{100}$ (1882), a Negro boy of twelve was indicted for murder in the first degree, having killed another youth, aged seventeen, by stabbing him in the heart with a pocket knife. Witnesses for the prosecution testified that the two boys were often fighting and that the defendant killed the deceased when he was attacked with a pitchfork. The jury found the defendant guilty of first degree murder. The Morgan Circuit Court of Missouri reversed the judgment; the higher court held that a lesser degree of homicide would have been more appropriate, aside from the fact that "no effort seems to have been made at the trial to show the defendant possessed criminal capacity." 101

The criminal responsibility of children in the United States during the nineteenth century was determined according to traditional principles of English law and by the elaboration of rules of procedure and evidence, which leaned toward the protection and benefit of the defendant. There seems to be no justification for the proposition that children were regularly executed; on the contrary, the courts were extremely hesitant to sentence a child under fourteen to death and, where such a case arose, it was either appealed by the defense counsel or certified by the trial judge to the state supreme court. According to contemporary judicial records and legal textbooks, it appears, that only two children under fourteen were judicially executed between the years 1806 and $1882 .^{102}$

97 Id. at 212-13.

9815 S.C. 409 (1881).

99 Chief Justice Simpson held that: "Out of tenderness to infants-the ease with which they may be misled-their want of foresight and their wayward disposition, no doubt, the evidence of mahice, which is to supply age, should be strong and clear beyond all doubt and contradiction; ... but we find no authority for the position that this evidence must be outside of the facts of the offence itself ...." Id. at 414 .

10076 Mo. 355 (1882).

101 Id. at 358. "But we are very clearly of opinion that the court erred in its view of the law touching the age of defendant. We refer to the third and seventh instructions given at the instance of the State. Those instructions virtually told the jury that the defendant's age should not affect the conclusion at which they should arrive, any more than if he had been of mature years. This is not the law." Id. at 358 .

102 Godfrey v. State, 31 Ala. 323 (1858); State v. Guild, 10 N.J.L. 163 (1828). 
In both cases, the defendants were Negro slaves and, in one case, the victim was the son of a white property owner. ${ }^{103}$

In the fourteen cases ${ }^{104}$ on the criminal responsibility of children in the United States between 1806 and 1882, the "good and evil" or "right and wrong" test was used ten times and in one other case, Godfrey v. State,$^{105}$ a similar test was substituted. In one case, State v. Bostick, ${ }^{106}$ no specific test was inentioned because the appeal rested on the issue of the admissibility of confessions; in the two remaining cases, no particular test was used. Of the fourteen children tried, seven were indicted for murder, one for manslaughter, five for various degrees of larceny, and one for malicious trespass. In ten instances the jury returned a verdict of not guilty; two children, aged eleven and twelve, were executed, and the remaining child, aged eight, was sentenced to three years in a state prison.

\section{B. Criminal Responsibility of the Insane, 1800-1843}

Much has been written in criticism of the $M$ 'Naghten rules since their pronouncement in 1843 , but few historians have considered the legal development of the "good and evil" or "riglit and wrong" test prior to M'Naghten's Case. ${ }^{107}$ James Hendrie Lloyd dismissed this test as a common law doctrine of no great antiquity. ${ }^{108}$ Weihofen agreed with the legal historian, Stephen, that early legal materials concerning the responsibility of the insane slould be treated as "antiquarian curiosities."109 The Royal Commission on Capital Punishment further noted that "little need be said of the development of the law before the case of M'Naghten in 1843." "110

The four leading works on the history of criminal responsibility in the United States generally endorse this view and attach no historical or legal significance to pre-1843 tests of legal insanity. The historical chapters in these works usually begin with the incorporation of the M'Naghten rules into American case law after 1843 and do not account for the legal cliniate whicl facilitated the acceptance of these rules. Lloyd, ${ }^{111}$ Glueck, ${ }^{112}$

103 There is a possibility that in the other case, State v. Guild, supra note 102, the victim was also white.

104 See summary of cases in Table $I$, in Appendix.

10531 Ala. 323 (1858).

1064 Del. (4 Harr.) 563 (1845).

107 Psychiatric dissatisfaction with the M'Naghten rules has been well summarized in Alien, The Borderland of Crmmal Justice 109-13 (1964).

108 Lloyd, Insanity: Forms and Medico-Legal Relations, in WHARTON \& Stmaté, MEDICAL JURISPRUDENCE 535 (5th ed. 1905).

109 Wemogen, Insantiy as a Defense in Crtminal Law 17 (1933).

110 Royal Comomission on Capital Punsmanent, Final Report 397 (1949-53).

111 Lloyd, supra note 108 , at 554.

112 Grueck, Mentax Disorder aNd the Crmminal Law 153 (1925). 
Weihofen, ${ }^{113}$ and Deutsch ${ }^{114}$ discount any historical justification for the "good and evil" and "right and wrong" tests. According to Glueck, for example, "there is nothing inherently sacred in the origin of these tests, nothing absolutely authoritative in them, nothing very consistent in them, and no very good reasons why they should not be changed."115

Inquiry into the origins of criminal responsibility has been extremely himited and has relied, for the most part, on secondary sources. The standard and most widely used reference in the United States is the fifth edition of Wharton and Stille's Medical Jurisprudence, which includes the first comprehensive survey of the historical development of tests of responsibility for the insane. ${ }^{116}$ In this treatise, James Hendrie Lloyd observed that the "right and wrong" test was a "brand new formula," which was "adopted arbitrarily by the courts" in the United States after 1843.117 Both Weihofen and Deutsch nodeled their historical ehapters on Lloyd's survey and consequently accepted his initial premise. Glueck, however, did go beyond existing knowledge and suggested that the "good and evil" test was "well established in New York and in some, if not all, the states" before $1843 .{ }^{118}$ Glueck's impression, based on the evidence of ouly two cases, was in fact correct although he did not attempt to systematize his findings or evaluate their historical implications.

The culpability of the criminally insane in American law during the nineteenth century was determined according to the traditional principles of English law, reinforced by the ideas and emerging expertise of medical jurisprudence. Many of the earliest American commentaries on criminal law, such as Bishop's Commentaries on the Criminal Law, ${ }^{119}$ and The Crowen Circuit Companion, ${ }^{120}$ were merely abridgments of English works by Coke, Hale, Hawkins, and Blackstone. As early as 1792, one such commentary included a reference to the "good and evil" test in a discussion of principles relating to the insane offender. ${ }^{121}$

The traditional assumptions underlying tests of criminal responsibility were approved by both lawyers and physicians. The stereotypic definitions

113 See WeIHores, op. cit. supra note 109, at 14-44.

114 Deutsch, The Mentalix InI IN AMerica 387 (1960).

116 Grueck, op. cit. supra note 112 , at 157 .

116 The earlier editions of Wharton and Stille's Medical Jurisprudence, published in $1855,1860,1872$, and 1882 , do not include a comprehensive survey of the history of legal insanity. In the fifth edition (1905), according to the preface, "the whole subject of the medical jurisprudence of insanity has been written by Dr. James Hendrie Lloyd. This is therefore an entirely new work, not a mere edition of the former volume."

117 Lloyd, supra note 108 , at 556.

118 GLUECK, op. cit. supra note 112 , at 154 .

119 Bishop, Comotrantartes on tere Crmmanat LAw (1856).

120 The Crown Circuit Companton (1816). See also Browne, The Elmaneants or Crmarmat LAW (1892).

121 BurN, AbridgmeNt, or the AuErican JUstice 300 (1792). 
of insanity were not peculiar to legal reasoning but were also implicit in the ideas of professional personnel from medicme and related disciplines who supported the philosophy of deterrence and the strict control of social deviants; the "right and wrong" test was considered bad medicine but good law.

Writers such as Highmore, Collinson, Farr, Cooper, Dease, Prichard, Haslam, and Wood, who founded the discipline of medical jurisprudence in England, generally were agreed that there existed a wide range of inental illnesses which lay outside the scope of the traditional legal tests of responsibility. Dease, for example, noted that:

There are ... many instances of decided insanity, where the patient cannot write and read, but converse and argue closely and accurately on every subject, except that on which he is insane. ... It is a false notion that madmen cannot reason; they often reason with accuracy on many subjects, and carry into execution plans, which require subtlety and long-continued dissimulation . . . . ${ }^{122}$

It was felt, however, that such a mental illness should only excuse an offender if, "at the period when he committed the offense," he was "wholly mcapable of distinguishing between good and evil."123 Dease, a surgeon, felt that punishment was a valuable deterrent whose utilitarian functions precluded clinical interests. He argued that the "improper extension [of the right and wrong test] would become a cloak for crimes, which would ultimately tend to the mjury of the community and the subversion of social order."124 Another physician, William Wood, echoed these sentiments and "totally repudiated the doctrine that an insane person is necessarily irresponsible":

[W] hilst we are tenderly alive to the frailties of our common nature, and feel it to be a christian obligation to shield from man's vengeance one already withering under the chastening hand of God, we yet, as good citizens, have a solemn duty to perform towards society, and our responsibility is immensely increased when, as members of a learned and honourable profession, we are called upon to assist, with our experience, in deciding whether or not the evidence adduced in defence of a criminal is sufficiently clear to justify the administrators of the law in departing from the course which is essentially necessary for the safety of society, and the protection of the lives and property of individuals. ${ }^{125}$

122 Male, Epitome of Juridical or Forensic Medicine in TraCtS ON MEDICAI JURISPRUDENCE 251, 254 (Cooper ed. 1819).

123 Cortinson, IDIots, Lunatics, and other Persons Non Conpotes Mentis 474 (1812).

124 Male, supra note 122, at 255.

125 Wood, Reacaris on the Plea of Insantiy and on the Manageasent of Crominai Lovatics 4-5 (2d ed. 1852). 
It is likely that American judges of the nineteenth century were familiar with the English literature of medical jurisprudence (which, if anything, supported and encouraged the use of the right and wrong test of criminal responsibility) as there were few comparable American resources. ${ }^{126}$ Benjamin Rush's classic treatise, Diseases of the Mind, first published in Philadelphia in 1812, did not deal with the problem of criminal responsibility but was more concerned with the treatment of deviant behavior. The first comprehensive American text on medical jurisprudence was written by Theodric Beck in $1823,{ }^{127}$ and cited Bellingham's Case ${ }^{128}$ as the leading authority of Enghish law and, in so doing, approved the use and assumptions of the "right and wrong" test. "By these principles (of Bellingham's Case)," he wrote, "the criminal jurisprudence of England and this country has been guided, and decisions conformable to them have repeatedly been made. They are doubtless correct, and conducive to the ends of justice."128

Before $M^{\prime}$ Naghten's Case, ${ }^{130}$ we find almost no criticism of the "riglt and wrong" test in the United States; only the renowned forensic psychiatrist, Isaac Ray, poimted out that such a test was inconsistent with psychological knowledge of liuman behavior. He characterized the criminal law as clinging to "crude and imperfect notions" of insanity.

In their zeal to uphold the wisdom of the past, from the fancied desecrations of reformers and theorists, the ministers of the law seem to have forgotten that, in respect to this subject, the real dignity and respectability of their profession is better upheld by yielding to the improvements of the times and thankfully receiving the truth from whatever quarter it may come than by turning away with blind obstinacy from everything that conflicts with long-established maxims and decisions. ${ }^{131}$

Ray's main objection to the "right and wrong" test of responsibility was based on the "well established" proposition that "the insane mind is not entirely deprived of [the] ... power of moral discernment, but on many subjects is perfectly rational and displays the exercise of a sound and well balanced mind."132 Ray's objections, however, had little effect on American criminal law during the mineteentl century.

American courts accepted the "right and wrong" test long before

126 Halleck, American Psychiatry and the Criminal: A Historical Review, 121 AMERICAN J. of Psychlatry No. 9, i-xxi (1965).

127 Beck, Elements of Medical. JuRisprudence (1823).

128 Cournson, op. cit. supra 123, at 657 . See text accompanying note 58 supra.

1291 BECK, op. cit. supra note 128 , at 369-70.

13010 Clark \& F. 200, 8 Eng. Rep. 718 (1843).

131 Ray, Medicat, Jurisprudence of Insanity 13 (3d ed. 1853).

132 Id. at 32 . 
1843, as the following cases, reported between 1816 and 1838, demonstrate. The cases also give clues as to how insanity was pleaded and proved and the criteria used by judges and juries. These cases were considered authoritative by leading contemporary commentators, and they were cited in textbooks on criminal law in the latter part of the nineteenth century.

In Cook's Case ${ }^{133}$ (1816), the defendant was indicted for grand larceny. His counsel claimed that the defendant was an idiot, a fact which could be ascertained by "ocular demonstration." The defense counsel introduced no supporting expert testimony but "informed the jury that he possessed a knowledge of physiognomy and that madness itself was stamped on every lineament of the prisoner's countenance by the hand of nature." "I do aver," he said, "every movement of that head, every glance of that vacant, staring eye-nay his whole exterior, indicates downright madness." Under questioning, the defendant "answered with pecuhar facial gestures," which the court did not accept as "positive proof of madness." The jury quickly pronounced him guilty, and he was sentenced to the state prison for three years.

In Clark's Case $^{134}$ (1816), Richard Clark, indicted for petit larceny, was described by the prosecution as "one of the many foreigners who come to this country with an exalted idea of their own consequence, and with a certain haughty demeanor, not adapted to the simplicity of our manners. Such an one, we admit, may live in this country, should he have the means to buy." After a plea of insanity had been entered, the Mayor charged the jury that:

[S] uch was the humanity of the law, that no man could be held responsible for an act committed while deprived of his reason .... . [A] madman [is] . . . generally considered, in law, incapable of committing a crime. But it is not every degree of madness or insanity which abridges the responsibility attached to the commission of crime. In that species of madness, where the prisoner has lucid intervals, and when capable of distinguishing good from evil, he perpetrates an offense, he is responsible. The principal subject of inquiry, therefore, in this case, is whether the prisoner, at the time he committed this offense, had sufficient capacity to discern good from evil. ${ }^{135}$

The jury accordingly found the defendant guilty, but the court suspended sentence for the purpose of "speedily sending the prisoner back to his native country."

Traux's Case $^{136}$ (1816) demonstrates how the insanity defense could

1831 City-Hall Recorder (New York City) 5 (1816).

134 Id. at 176.

135 Id. at 177 .

130 Id. at 44. 
be used as a fiction to disguise discriminatory findings. Unlike the defendant in the previous case, Isaac Traux was a "gentleman of good breeding," and "it clearly appeared that he was a young man of property and respectable connexions in the city of Albany, but that lis senses had been impaired, and his moral faculties totally ruined by the excessive use of ardent liquor." He was immediately acquitted by the jury and the presiding judge suggested that "he ought to be taken from the city to his friends, in whose custody lie ought to remain."

In Sellick's Case ${ }^{137}$ (1816), the defendant was indicted for murder by poisoning. Diana Sellick pleaded insanity; there was "the absence of all inotive." The judge instructed the jury that "the evidence of insanity should not only be conclusive, but overwlelming":

Insanity is a defence often resorted to, and in most cases, when every other ground of defence has failed. ... In my view, such a defence, in such a case, ought to be scrutinized by the jury with no ordinary degree of caution. It does not follow, by any legitimate rule of reasoning, that because we are unable to penetrate into the motive which induced the act, that we are therefore to attribute the act to insanity. In her examination she says she was possessed with the devil, and knew not what she did. Can we reasonably look for any other motive than that laid in the indictment? ${ }^{138}$

Following this instruction, the jury quickly found the defendant guilty and the judge, "in a solemn, pathetic address," sentenced ler to "be hanged by the neck until dead."

In Ball's Case $^{139}$ (1817), the defendant was indicted for wilfully and maliciously setting fire to a dwelling louse. In his defense, it was pointed out that he was an old man "with liabits of brutal intoxication" and "violent vindictive passions." The Mayor instructed the jury that revenge or despair was not a sufficient defense. "It did not necessarily follow," he said, "that the act of which he had been charged was the result of insanity because, from its nature, it was horrid and unnatural." The only question to be determined in the case, continued the Mayor, "is whether, at the time le committed the offence, he was capable of distinguishing good from evil." The defendant was accordingly found guilty and fined by the court.

In Pienovi's Case $^{140}$ (1818), an Italian immigrant was indicted for an assault and battery; le was charged with maiming his wife by biting and tearing off the tip of her nose. The case created a great deal of

137 Id. at 185 .

$138 \mathrm{Id}$. at 190.

1392 City-Hall Recorder (New York City) 85 (1817).

1403 City-Hall Recorder (New York City) 123 (1818). 
public excitement, for the court reporter described Mrs. Pienovi as a "woman remarkable for her beauty. Considering the ideas entertained by the sex in general relative to their personal appearance, this was certainly one of the most insidious acts of revenge that was ever conceived and perpetrated." The defendant pleaded insanity, and his counsel argued that, at the time of the offense, he exhibited every "symptom of derangement" and "an air of wildness, indicative of phrensy." After at least seven witnesses testified that the defendant was either greatly "disturbed" or "deranged," the defense counsel asked the jury to acquit the prisoner because "at the tinue he committed the act charged in the indictment, he had not a mind capacitated for distinguishing good from evil."141

In response, the prosecution observed that he could "distinguish good from evil," a fact which was demonstrated by his "cunning and intelligence." The Mayor, in his instructions to the jury, emphasized the "good and evil" test of responsibility and stated: "A man should never suffer himself to be hurried into a state of temporary insanity by any of the violent passions. It is the universal language of the law - Govern your passions: for if you do not, you sliall be punished. . . . The Jury ... will determine whether at the precise point of time in which the act was perpetrated, he was capacitated for distinguishing good from evil."142 The jury found the defendant guilty but recominended nercy, which was not granted by the Mayor. According to the court reporter, "after a most inipressive address to the prisoner on the shocking deed of which he had been convicted, wherein his honour said that a crime of this precise description had never before ... been perpetrated in the United States, and he trusted in God never might be committed by any of its citizens, the prisoner was sentenced to the penitentiary for two years.".143

In Meriam's Case ${ }^{144}$ (1810), the defendant, who previously had been adjudged insane and "committed to the house of correction, as one too dangerous to go at large," was imdicted for murder. The court found the defendant "not guilty by reason of insanity." A court reporter, commenting on Meriam, restated the rules of responsibility for the insane offender: (1) Insanity is a defense of last resort; (2) insanity slould be clearly proved when relied on for a defense; (3) shocking or "unnatural" crimes do not presuppose insanity; (4) "frenzy" and "violent passions" are not synonymous with insamity; (5) a defense of insanity

141 Id. at 126.

142 Id. at 126-27.

143 Id. at 127 .

1447 Mass. 168 (1810). 
is to be strictly examined; and (6) the only question to be determined is whether the defendant, at the time of the crime, was "capable of distinguishing good from evil. ${ }^{3145}$

In United States v. Clarke ${ }^{146}$ (1818), the defendant was indicted for the murder of his wife. In his defense it was claimed that he suffered "from long and settled habits of intemperance, had become disordered both in body and mind, and subject to fits which affected both his mind and body." The presiding judge instructed the jury that:

[I]f they should be satisfied, by the evidence, that the prisoner at the time of committing the act charged in the indictment, was in such a state of mental insanity, not produced by the immediate effects of intoxicating drink, as not to have been conscious of the moral turpitude of the act, they should find him not guilty. ${ }^{147}$

The jury found the defendant guilty, and he was sentenced to death.

In People v. Tripler ${ }^{148}$ (1822), the defendant, who was charged with stealing five silver spoons, entered a plea of insanity on the grounds that her head was "affected by a fall" and "her conduct was strange." The court's instructions to the jury departed from the traditional principles of evidence by placing the burden of proof on the prosecution:

Although the defence has not been satisfactorily made out, yet there was quite enough made out to raise a doubt in the mind of the court, of the prisoner's being a person of a sound mind; and where a doubt exists, it would always be the safest way to acquit: insanity itself is calamity enough, without inflicting the pain of a conviction and its consequences. The witnesses have not shown any particular act whereby we could discover derangement, yet it is sufficient to say that a doubt has been raised, and that doubt ought to operate in favour of the prisoner. ${ }^{149}$

Hadfield's Case $e^{150}$ was the first English decision to explicitly reject the "good and evil" test of responsibility for the insane offender. In the United States, the court reporter in Tripler ${ }^{151}$ and the defense counsel in People v. De Graff ${ }^{152}$ argued for the incorporation of the principles of Hadfield's Case into American law. This would have had a liberalizing effect on the traditional tests of responsibility by allowing broader interpretations of the "good and evil" test.

1456 City-Hall Recorder (New York City) 162 (1822).

14625 Fed. Cas. 454 (C.C.D.C. 1818).

147 Ibid.

1487 City-Hall Recorder (New York City) 48 (1822).

149 Id. at 49.

15027 HOWEIL 1281 (1800).

1517 City-Hall Recorder (New York City) 48, 51 (1822).

152 Id. at 203. 
De Graff, who was indicted for forgery, entered a plea of insanity on the grounds that he had "for the last six months, acted as if he was 'shattered,' and conducted himself very strange, [and] was different from what he used to be." Counsel for the defense contended that the prisoner was "apparently insane" and he introduced the testimony of neighbors who "were unanimous in the opinion that he was crazy." The defendant was "a member of the church," he continued, "and it was extremely improbable that a man in his situation would voluntarily plunge himself into such a depth of guilt." In conclusion, the defense admitted that the plea of imsamity was not made out to the complete "satisfaction of the Court, yet but if there was a doubt of his insanity, that doubt ought to be put in the scale of mercy."

The prosecution argued that the insanity defense was too readily made, and that he saw in the defendant "no indication of a defective mind: his whole demeanour was shrewd and acute. His conduct, from the beginning to the end, was indicative of his criminal intent, and not of unsound mind." The presiding judge concurred with the prosecution, and the jury returned a verdict of guilty against the prisoner. The court reporter referred to the Tripler case, and noting the conflict as to quantum of proof created by this case, restated the law, suggesting that the "good and evil" test was still the prevailing test of criminal responsibility. ${ }^{153}$

In Commonwealth v. Miller ${ }^{154}$ (1838), the defendant, aged twentythree, was indicted for murder in Pennsylvania. The prosecution estabhished that Williain Miller stationed himself by the side of a public highway and waited for his victim; "a pedlar soon made his appearance and while he was stooping down to take some articles out of his pack to exhibit to Miller, the latter killed him with his axe." The defense, "in their anxiety to do all in their power to save the prisoner's life," argued that their chent was insane as a result of "monomania" and, to this effect, they introduced the expert testimony of "a celebrated phrenologist," $\mathrm{O}$. S. Fowler. ${ }^{165}$

In his instructions to the jury, Judge Elhis Lewis equated "moral insanity," the irresistible propensity for violence arising from "an undue

153 Id. at 218.

1541 Phrenological J. 272 (1839), cited in Lewis, AN Abridgment of the Crintinal LAW OF THE UNITEd STATES 399-401 (1848).

155 Id. at 400 . Fowler described the defendant as "of the lymphatic temperament; and stated that persons of this temperament are more apt to be deranged upon the animal passions than upon the intellectual or moral faculties. He also, among other things, described the prisoner's phrenological developments as they appeared to him on an examination some days previously in the prisoner's cell. The organs of 'Destructiveness, Secretiveness and Acquisitiveness,' were stated by Mr. Fowler to be immense, the head measuring about seven and a quarter inches in diameter from ear to ear." Ibid. 
excitement of the passions," with "vice" and held that "it is not generally admitted in legal tribunals as a species of insanity which relieves from responsibility for crime, and it ought never to be admitted as a defence until it is shown that these propensities exist in such violence as to subjugate the intellect, control the will, and render it impossible for the party to do otherwise than yield." The judge questioned the scientific validity of the expert testimony of $O$. S. Fowler concerning the defendant's "moral insamity."156 The court suggested that "monomania," might constitute a successful defense:

It was stated to the jury, that the court could perceive no sufficient evidence of delusion or hallucination on any subject to establish the existence of monomania; still, if the jury believed that the prisoner was, at the time of committing the act charged, "incapable of judging between right and wrong, and did not know that he was committing an offence against the laws of God and man," it would be their duty to acquit. ... 167

The jury found the defendant guilty of murder, and the court sentenced him to death. Judge Lewis, in a letter to the American Phrenological Journal in 1839 , reported that the prisoner "made a full confession, appeared much affected with his situation in reference to a future world, seemed truly pemitent, and met death with great firmness, even assisting the sheriff in some of the last sad offices of the melancholy scene."168

Thus, in twelve ${ }^{159}$ cases on the criminal responsibility of the criminally insane offender in the United States between 1816 and 1841,

156 The scientific authenticity and medical proof of phrenology in the nineteenth century raised the same kind of doubts for judges and juries as does the concept of psychopathy today.

157 Lewis, op. cit. supra note 153, at 401. (Emphasis in original.)

158 In an interesting postscript to this case, the editors of the Phrenological Journal reconstructed a crude case history of William Miller to explain his "vicious and criminal conduct and the gradual process by which he became so hardened and cruel." Miller's parents were poor, but "not in absolute poverty," and they had "never shown as much attention to education as people generally do, and their unhappy son was said to be exceedingly illiterate. His mother died when he was quite young. He was subject to little if any, parental restraint and government; received, comparatively, no education, nor moral and religious instruction; early gave way to his 'evil passions'; was greatly encouraged by bad associates; was not restrained by the ties of family affection, nor influenced much by any relations to friends and acquaintances, either in regard to his business or his character; first commenced stealing little things, then lying; persevered constantly in sucb offences for nearly fifteen years, till he finally committed robbery and murder. But it appears that he had planned several murders, and even that of his 'own' brother, before the execution of his last fatal deed. Let every reader observe that Miller grew up with his intellectual faculties 'uneducated', his moral sentiments unenlightened, his domestic feelings 'but little exercised', and his selfish propensities and sentiments 'unrestrained'. We need not say, that these facts involve important principles in the true physiology of the brain and the science of mind."

159 The twelfth case, People v. Abbot (1841), is cited by RaY, op. cit. supra note 132, at 55. See summary of cases in Table II, in Appendix. 
the "right and wrong" or "good and evil" test was used seven times and various synonyms were used on three other occasions. As for the two remaining cases, one was based on a plea of drunkenness and the other did not explicitly refer to any test of responsibility. Five cases involved an indictment for murder, four for larceny, and one each for arson, forgery, and assault and battery. According to the judicial records, the plea of insanity was successful only in three cases and, of the remaining nine prisoners who were found guilty, three were sentenced to death and executed. This evidence suggests that American courts were already using a "right and wrong" test of responsibility for the insane long before 1843 and that they were willing to acknowledge the M'Naghten Case as something not too foreign to their own experiences. The M'Naghten rules, therefore, offered an opportunity to American courts to solidify and legitimate, rather than change, standard practices.

The history of the "right and wrong" test in the United States after 1843 has been well documented in the hiterature. This test became obsolete with regard to children following the emergence of the juvenile court system at the end of the last century, thougli there is considerable debate as to whether such a test should be revived on the grounds that it gnarantees either the constitutional rights of the defendant or the criminal law's effectiveness as an instrument of moral education. ${ }^{180}$

As far as insanity is concerned, most American states formally adopted the "right and wrong" test of responsibility after the trial of Daniel M'Naghten in 1843. Chief Justice Shaw, in Commonzealth v. Rogers ${ }^{101}$ (1844), generally has been acknowledged as the first American judge to cite M'Naghten's Case as an authority for the "right and wrong" test. This test was eventually approved in most states, and it was first cited in California in People v. Coffman (1864). ${ }^{162}$

In some states the "right and wrong" test has been supplemented by other derivative rules, notably the "irresistible impulse" test. New Hampshire, under the influence of Isaac Ray, rejected the "right and wrong" test and substituted a test whiclı exempted from responsibility a defendant whose crime "was the offspring or product of mental disease."1163 Despite numerous attempts to modify the M'Naghten rules, the "right and wrong" test continues to be the traditionally accepted test of responsi-

160 This conflict between the "legal moralists," represented by Stephen, Denning, Devlin, Goddard, and Wigmore, and the "constitutionalists," represented by Francis Allen, Matza, Rubin, Jeffery, and Tappan, has been partially analyzed by HART, LAW, LIBERTY AND MORAIITY (1963).

16148 Mass. 500 (1844).

16224 Cal. 230 (1864).

163 State v. Jones, 50 N. H. 369 (1871); State v. Pike, 49 N. H. 399 (1869). 
bility. The Durham rule, ${ }^{104}$ the test proposed by the American Law Institute, ${ }^{165}$ the Currens rule, ${ }^{166}$ and other recent formulations have been accepted in only a few jurisdictions. ${ }^{167}$

\section{CONCLUSION}

The evolution of the "right and wrong" test of criminal responsibility can be traced from Hebrew law, Greek moral philosophy, Roman law, the hiterature of the Church in the Middle Ages, and English common law to its final elaboration in American case law. There is substantial evidence to suggest that the role of the child, as a prospective member of adult society, was an expedient and ideologically meaningful reference for rules of criminal responsibility for the insane criminal offender. The "right and wrong" test was used in England to determine the criminal capacity of children as early as the fourteenth century and of the insane probably by the seventeenth century. It has been used widely in the United States for both children and the insane since 1800 .

It is clear that the "right and wrong" test of criminal responsibility did not arise in 1843, either in England or in the United States. The "knowledge of right and wrong" test, in the form of its earlier synonym ("knowledge of good and evil"), is traceable to the Book of Genesis. The famous M'Naghten trial of 1843 and the subsequent opinion of the judges provided only the name, "M'Naghten Rule." The essential concept and phraseology of the rule were already ancient and thoroughly embedded in the law.

$16 \leq$ Durhanı v. United States, 214 F.2d 862 (D.C. Cir. 1954).

165 Moder Penal Code $\$ 4.01$.

106 United States v. Currens, 290 F.2d 751 (3d Cir. 1961).

167 For a discussion of these tests and also California's experience with the test of "diminished responsibility," see Diamond, Criminal Responsibility of the Mentally Ill, 14 Staw. L. Rev. 59 (1961). Diamond, From M'Naghten to Currens, and Beyond, 50 CaLrF. L. REv. 189 (1962). 


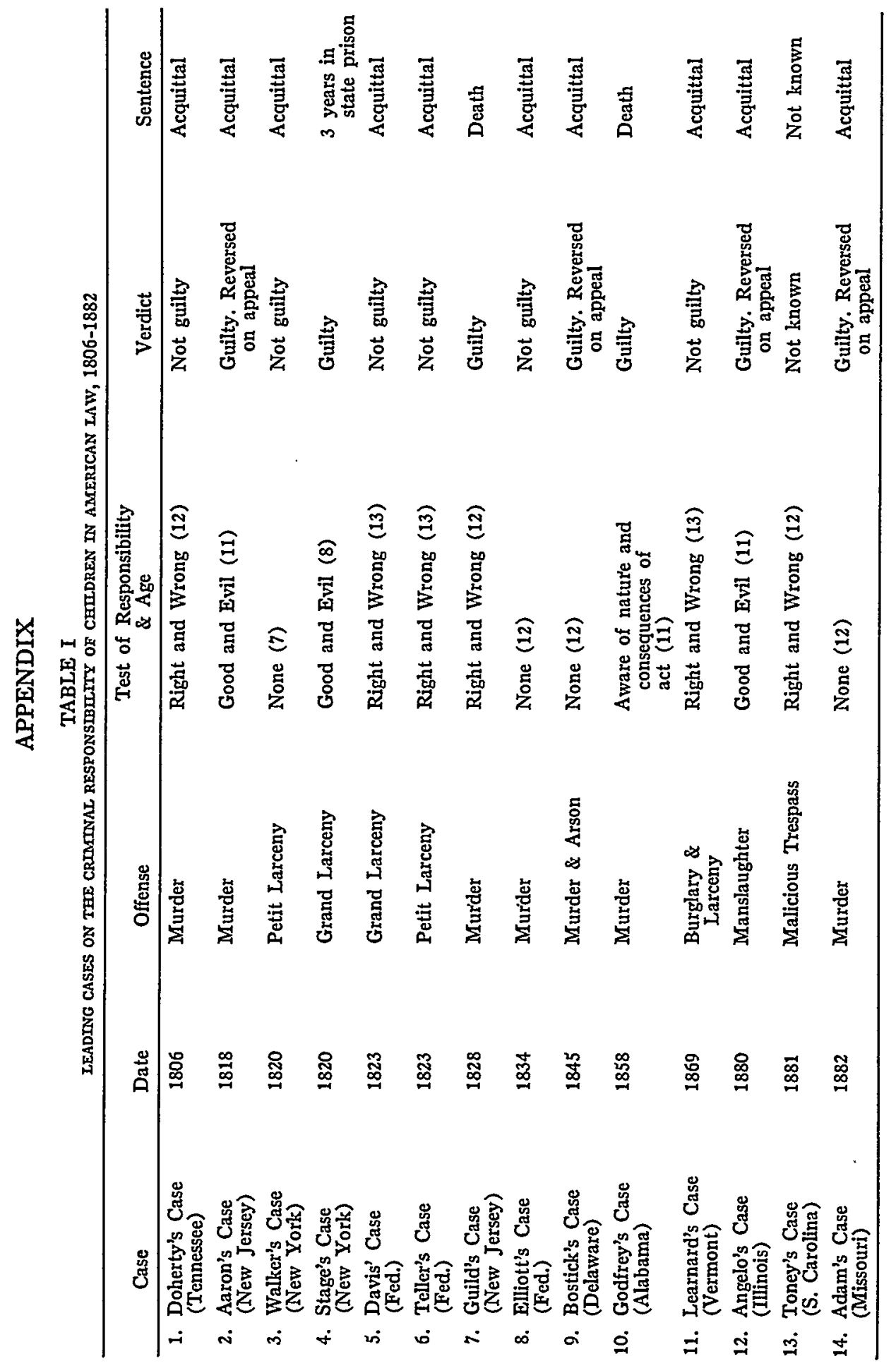




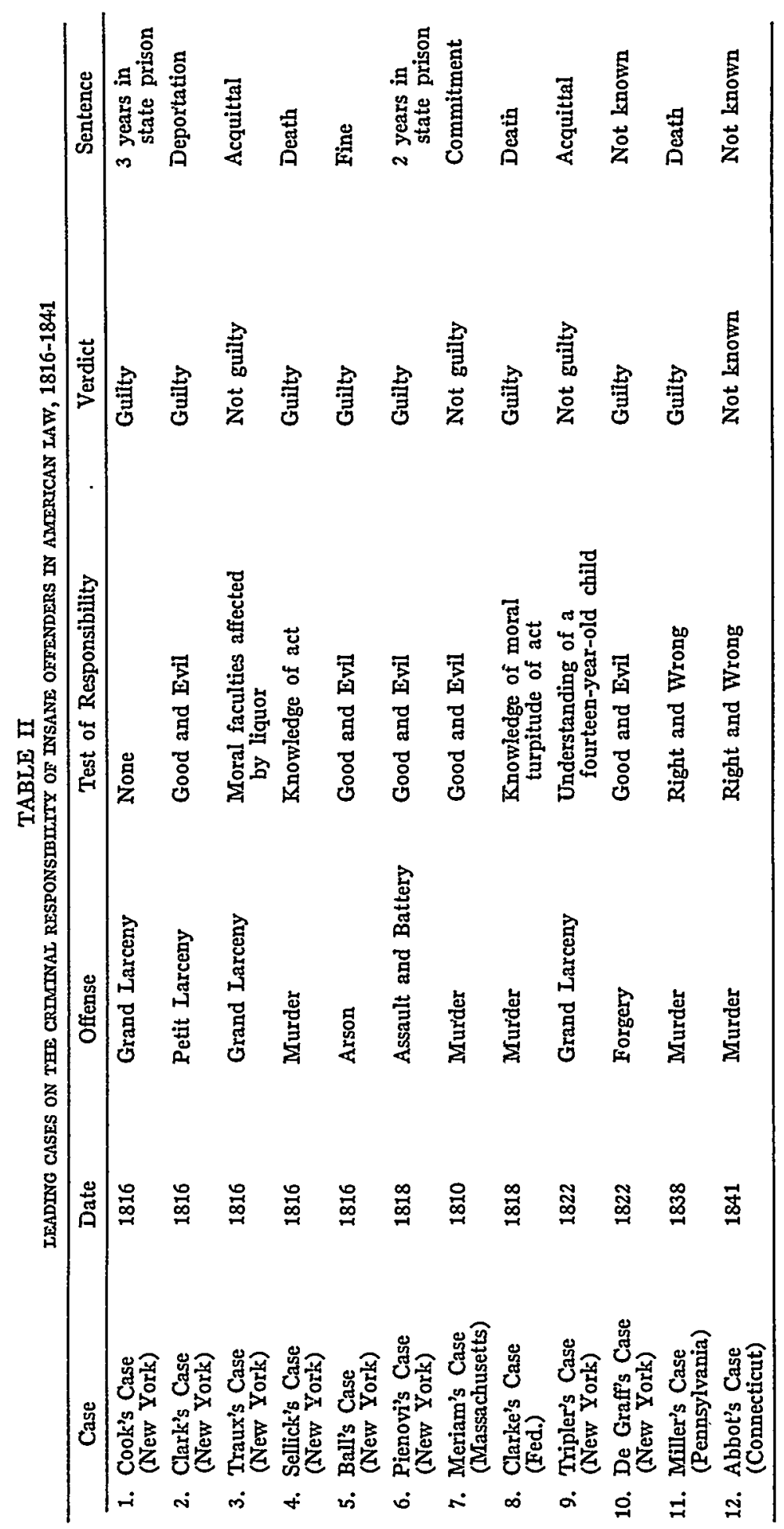




\section{California Law Review}

\begin{tabular}{lll}
\hline \hline VoL. 54 & AUGUST 1966 & No. 3 \\
\hline \hline
\end{tabular}

BOARD OF EDITORS

Cart J. Senerer II

Editor-in-Chief

CharLes II. Wilson, Jr.

Managing Editor

Barbara Brodno Gardier Article Editor

DAVm ATAN LEIPZIGER Article Editor

Davm B. Frommacayer

Research and Chief Note \& Comment Editor

EDMUNd R. MANWEIT

Book Reviezu Editor

Myron G. Sugaracan

Business Editor

JERRY J. BerMaAN

Note $\&$ Comment Editor

Grorge A. Cuname, JR.

Note \& Comment Editor
KenNeTH A. Goldman

Note \& Comment Editor

ALEXANDER M. HeHaneyer

Note \& Comment Editor

Robert CARI HerR

Note \& Comment Editor

Sandra Terzan

Note \& Comment Editor

Tract A. Westen

Note \& Comment Editor

STANLEY H. Wintiates

Note \& Comment Editor

KELIY C. WOOSTER

Note \& Comment Editor

\section{Associates}

Robert H. BErger

Robert ALAN BLUM Atan G. Cartton

Tom A. Dowse

MITCHAET A. FISCHER

DANIEL S. Frost

Ttarothy Drexrus

Mitceaet C. Ferguson

Janet FrIEDMaAN
Donato S. Greenberg

StepHen H. GreEnLeAF MarTin E. Harband

DaLLas Holmes

RICHARD C. HUNT

\section{Candidates}

Atison M. Gret

ALAN E. HARRIS

Donatas Januta

George R. Poenter

Marjorte Devereux

Administrative Assistant
STEVEN M. KTPPERMAN

Rtchard S. Piatz

NoRMAN ERNEST RETTZ

Wilitara T. RINTALA

SeIvta Sejoex

GARY E. THACHER

Jomn F. PrtTchard

WIILiAar Roger StrejoW

Peter K. Westen 